\title{
Are Brand Communities Influencing Brands through Co-creation? A Cross-National Example of the Brand AXE: In France and in Tunisia
}

\author{
Héla Cherif ${ }^{1} \&$ Ben Miled $^{1}$ \\ ${ }^{1}$ Research Center PRISM, France \\ Correspondence: Héla Cherif, Université Paris 1 Panthéon Sorbonne, 1, Rue Victor Cousin, 75005 Paris. E-mail: \\ helacherif1@yahoo.fr
}

Received: September 17, 2012

Accepted: October 11, 2012

Online Published: August 20, 2013

doi:10.5539/ibr.v6n9p14

URL: http://dx.doi.org/10.5539/ibr.v6n9p14

\begin{abstract}
In order to build long term relationships with customers, companies involve them more often on their activities. They are now "prosumers" through co-creation process and social media. The primary objective of this study is to identify, by means of a cross-national empirical study, if brand communities influence brand by co-creation. What kind of influence can the virtual brand community have on co-creation? The study begins by a conceptual framework on genesis of concepts of co-creation and brand community. After that clarification, methodology is developed and consequently results are exposed. Conclusions and managerial implications are then withdrawn. And finally limitations of the study and future researches are presented. Theoretical contribution of the study is as follows. Firstly, propose a new classification of co-creation. Secondly the use of Kapferer's brand identity Prism (1991) in order to create a strong brand seems to be helpful for building brand community. Thirdly a new method, the netnography, applied to "Axe" brand in France and Tunisia.
\end{abstract}

Keywords: co-creation; brand community, brand identity, netnography, Axe, Tunisia, France

\section{Introduction}

The status of the consumer has shifted from a passive one to one described as "prosumer" i.e. a proactive role. This role takes on full significance in the creation of new products and services. Indeed, brands are increasingly drawing on consumers' insights and associating them in the conception of the offer, fully aware of their valuecreation potential. This article argues that the customer will inevitably prefer the product or the service in which he has been participating. However, isn't putting the consumer at the centre of the value of the product or service - creation process the very foundation of marketing?

Web 2.0 has helped companies to increase initiatives to strengthen and reinforce their interaction with consumers. Consumers give their opinions, bring in new ideas, discuss, vote for a product or an advertising poster etc.: what is referred to as co-creation? Such actions take advantage of the success of social media and community websites. They promote the formation of communities whose members are no longer subjected to advertisements or other marketing strategies but, on the contrary, are entirely participating in the marketing process. These members are individuals sharing the same passion for a product or a brand and often bring in new ideas and trends. Companies have moved from a traditional marketing logic focused on consumption towards a participative model based on interaction between brands and customers. Indeed, brands are now creating online platforms and social networks pages devoted to the conception of new offers and ideas and are open to feedbacks (for instance Starbucks with 'My Starbucks Idea' and Nokia with 'Share Your Ideas'). Which has resulted is brand communities or, as Sitz and Amine put it "individuals sharing values, norms and representations emerging from similar consumption practices, from collective reception of advertising messages as well as from the visit of similar stores" (Sitz \& Amine, 2007).

Nowadays, companies create situations in which consumers can actively interact and develop personalised experiences (Valencia-Garcia, 2012); however, studies on the effects of co-creation brand communities on brands are limited. That is the reason why I intend to focus on such effects.

First of all, a literature review sheds light on the genesis of co-creation and brand community concepts. Definitions was provided and refining these concepts by differentiating them from other similar concepts. The brand's role in the relation between the brand community and co-creation is established. The second part 
highlights on the method. Qualitative interviews from experts and consumers by using the AXE brand as an example and comments from consumers, on social networks are gathered together in order to carry out to a netnographic study (Kozinets, 2002). Whereas the third part expose the result of netnographic study. After that, conclusion, discussion, as well as managerial implications are exposed and finally limitations and the future researches are presented.

\section{Conceptual Framework}

\subsection{A Theoretical Approach to the Co-Creation Concept}

Prahalad and Ramaswamy (2000) are the first to take a close interest in the co-creation concept by considering consumers as actors of the creation process. They exchange information and enter into explicit dialogues with companies. They have introduced a bilateral perspective for exchange (companies-customers dynamic). This thinking is complemented by Harris, Harris and Baron (2001) who have added participation to this concept and by Vargo \& Lush (2004) who have conceptualized the shift from the Product Dominant Logic (P-D Logic) to the Service-Dominant Logic (S-D Logic).

\subsubsection{Participation and Participative Marketing}

In this context, the terms collaboration, cooperation and contribution are all synonyms and can interchangeably be used with participation. The participative or collaborative marketing's primary goal is "to encourage consumers to actively participate in the elaboration of the product communication, the development of new services or the promotion of the brand's latest updates" (Harris, Harris, \& Baron, 2001). Moreover, participation can also take two forms: the behavioral or physical participation with, for instance the involvement in an activity; and intellectual participation such as knowledge sharing.

Participative marketing can take many different forms: voting for movies proposed by Air France on long distance flights, for a TV advertising script (Nespresso) or for the next catalog cover (Linvosges) ... In these examples, the product, the TV script or the catalog have been designed by the company. The consumer's task is simply to orient the company's choice between different options whether that concerns the organization of large-scale product or advertising testing for instance. This participative approach has been used by Starbucks with the launching of its ideas box "My Starbucks Idea" generating more than 75000 ideas, of which only a dozen have some practical application, the majority consisting of a basic improvement of existing products. In the same way, Carrefour has created a test panel for its products and has opened an ideas box to collect suggestions from more than 10,000 fans on Facebook. These two examples show how quantitative studies resorting to internet are growing. They allow to increase the sample size and to add an interpersonal perspective to the questioning process. The consumer is not certain that his opinion will be effectively taken into account and that his engagement toward the brand will be useful; his input could be minor.

Contrary to the examples seen above, real co-creation involves the upstream consumers in the creation process as well as those more actively engaged. Most of the time, co-creation deals with product design (Nivea, Lay's in Belgium ...) or with communication campaigns (Crédit Agricole, Dim ..).

Overall, in most studies consumers or customers are considered an integral part of a firm's production process (Mills \& Morris 1986). Customers' participation can be found during the "co-conception" product design phase. The "lead users", bringing in their expertise, can assist brands with the design of products. Their perceptions and preferences matter since they help identify future needs and, therefore, they contribute to the emergence of new products processes or services (Von Hippel, 1986). As Ezan and Cova argue: "the collaborative approach consists, in defining the characteristics of leader users, selecting individuals on the basis of these characteristics and soliciting them so that new products' concepts can emerge" (Ezan \& Cova, 2008).

\subsubsection{From the Product-Dominant Logic (P-D Logic) to the Service-Dominant Logic (S-D Logic)}

Marketing has inherited from a classic economic model based on a dominant logic of product exchange or of production units. Value is created during the production process and production units constitute the main components of the exchange. A normative framework separates production from product consumption without making consumers participate in the process: customers are thus exogenous and remain outside the manufacturing process. In recent years however, a new collaborative logic has emerged where the consumer partners up with the company: the Service-Dominant Logic (Vargo \& Lusch, 2004). The consumer becomes a co-producer and products become personalized so that they can adapt to customers' needs. Service refers to the process consisting in doing something with and especially to someone. ('Marketing with' takes precedence over 'marketing to') (Ezan \& Cova, 2008).

The term "servuction" is also used and is defined as "the systematic and coherent organization of all the physical 
and human elements of the interface client-enterprise necessary to the realization of a provision of services whose commercial characteristics and the levels of quality were given" (Meyronin \& Ditandy, 2011). This neologism refers to both the production system and the service distribution.

To conclude, the main difference between the SDL and the DPL lies in the management of all customers, employees and organizations. These intermediaries operate as resources in the value-creation process (Lusch \& Vargo, 2006).

\subsubsection{From a New Brands Logic in the Service-Dominant Logic (S-D Logic)}

Companies are now convinced that brands are essential for them and they have to mobilize the right resources in order to build strong brands (Madden et al., 2006; Simon \& Sullivan, 1993). Consumers and brand communities have to be involved in the brand's value creation process (Vargo \& Lusch, 2008).

Researchers underline the importance of new brands logic in which the brand value emerges from the interaction between all partners and companies. Consumers consider that brands are collectives' cultural goods and not an intellectual property of the enterprise (Cova \& Dalli, 2009).

Vargo and Lusch (2008) identify 4 historical periods for brand co-creation:

First period: (1900-1930) «individual goods-Focus Brand Era»: the brand is the identity of the product. Brand value results from products selling (exchange value). Consumers are passive in this value process (Fullerton, 1994).

Second period: (1930-1990) «Value-Focus Brand Era»: The brand has two functions: a functional and a symbolic one. Functional benefits result from physiological and security needs. Consumers choose brands in order to satisfy their consumption needs.

Symbolic Value-Focus Branding (Gardner \& Levy, 1955; Goffman, 1959; Levy, 1959) comes from self-expression needs and social acceptance. Symbolic brand value results from individual appurtenance to a desired group or to an ideal self-image (Park, Jaworski, \& MacInnis, 1986). Customers are still passive in the value process and brand value is created by selling products (exchange value).

Third period (1990-2000): relationship-focus Brand Era:

1) Customer-Firm Relationship Focus (Aaker, 1991; Blattberg \& Deighton, 1996; Kapferer, 1991; Keller, 1993): customers are active co-creators of the brand value.

2) Customer-Brand Relationship Focus (Aaker, 1997; Fournier, 1998; Gobe, 2001): The brand has a personality and consumers establish a dyadic relationship. The co-creation process results from the client-brand relationship.

3) Firm-Brand Relationship Focus (Berry, 2000; de Chernatony 1999; Gilly \& Wolfinbarger, 1998; King, 1991): customers are internal operating resources for firms which actively participate in the co-creation process for brand value.

Fourth period (2000 to ...): Stakeholder-Focus Brand Era: (McAlexander et al., 2002; Muniz et al., 2001; Muniz et al., 2005; Ballantyne \& Aitken, 2007; Ind \& Bjerke, 2007; Jones 2005): individual customers, members of brand communities and all stakeholders are operating resources. The co-creation process for brand value is continuous, social, dynamic and interactive between the firm and the brand. The co-creation can be on product use, on production and on offer design (Leroy, 2008).

\subsection{Tribal Approach Applied to Brand Community}

The tribal approach refers to the concept of the value of links in the interaction between members of a tribe (Cova, 2006). The concept of value differs from the value of conventional use associated with goods or services. The value of links implies that the firm contributes, through its products or brands, in addition to the mere delivery of products or the provision of services, to the construction, development and maintenance of tribal links between consumer groups or communities. The tribe can thus be interpreted as an "emotional grouping around the brand "or brand community. The advantage offered by a brand community over a consumer segment is that it involves interlinked actors capable of undertaking collective actions rather than grouping unrelated consumers presenting the same characteristics. The collective actions can be fostered through the use of social networking sites namely Facebook.

\subsubsection{Specificities of Brand Community}

Brand community is a group of consumers which shares the same cult of the brand. A sharing that generates myths, rites and symbolism qualified as sub-culture (Cova, Kozinets, \& Shankar, 2007). It is a passion that subsumes an "emotional and stable tendency" (Cova, 2011). It is a "living memory" nurtured by the firm and 
consumers as well as community members (Cova, 2006). Given the cross-national nature of the present study, Sitz and Amine's (2004) definition of brand community would be fitting "individuals sharing values, norms and representations emerging from similar consumer habits, collective reception of advertising messages as well as from the visit of similar stores. They recognize strong links of appurtenance between themselves and display an attachment to the brand".

Raies and Gavrard-Perret (2011) perceive the brand attachment as being bidirectional. Gupta and Kim, (2007) additionally see this attachment as a commitment to the community which can lead to brand loyalty (Algesheimer, Dholakia, \& Herrmann, 2005; Raies et al., 2011). The notions of brand community, tribes, sub-culture, attachment or commitment are then not geographically delimited. They transcend the boundaries of national territory.

\subsubsection{Interactions versus Paradox of Personal Branding}

The community of brand has two objectives (Cova, 2011):

$\rightarrow$ Contribute to social interactions between brand community members (e.g., BMW or Mercedes) for brand loyalty for community commitmentt. But if the consumer feel of strong pressure this community appurtenance can have a negative effects.

$\rightarrow$ Encourage consumer investment on community: it can be self-expure or a personal branding. For example, Ferrero brand with Nutella with « My Nutella the community » who create a sub-culture and reinforce the cult of brand. Consumer marketing replaces brand marketing through online platforms, blogs or the production of content which replace interactions. Social media are useful for personal branding and for all the communication strategies of communities. But generalist networks like Facebook can enrich interactions between community members. They can be useful for recruitment of fans and community members who share their passion on line and off line (For example Aubade lingerie brand, with its "seduction lessons" ad. However, social networks do not allow establishing constant dialogue with brand community.

\subsubsection{Brand Community: Transition from Target to Partner}

Employees, workers and customers are on an equal footing on building brand community. Employees can be brand consumers and customers can be events, ideas or brand accessory producers. This production can be helpful for companies if they recognize and accept that consumers have competences to modify and enhance companies offer. It is what Cova (2006) calls "consumer made". It is a strategy of ideas outsourcing, a process of co-creation of value between brand communities and firms which consists in giving one's opinion and producing novel and original ideas from members (products, services, experiences...).

\section{Method}

This study has undertaken a netnographic study. This method can be effectively carried out on the internet by studying brand communities (Kozinets, 2002). Hereafter the reason for the choice of this particular method will be presented. The brand which is the focus of this analysis, as well as the events illustrating the participative phenomenon will also be exposed.

\subsection{Justification of the Choice of the Methodology}

Netnography is a participant-observational method conducted on the internet (Giannelloni \& Vernette, 2012). It adapts ethnography's principles to virtual communities such as forums, newsgroups, chats or brand communities. This methodology provides information, meanings and describes consumption patterns of online groups (Kozinets, 2002; 2006). Such methodology implies the researcher's immersion into the virtual community long enough to familiarize himself with the community's culture - that is its values, norms, language, rituals... Kozinets describes netnography as a new qualitative research methodology that adapts ethnographic research techniques to the study of cultures and communities emerging through computer-mediated communications.... "It is a combination of more rigorous online guidelines combined with an innate flexibility" (Kozinets, 2002).

Hence, the methodology is the most suitable one to analyze communities' co-creation effects on brands. Indeed, discussion forums and social networks are platforms where consumers appear to be particularly interactive and creative.

\subsection{The Netnography Approach and Data Collection}

The netnographic study has followed the steps described below (Kozinets, 2002).

\section{$1^{\text {st }}$ step: Choice of relevant communities for research questions}

Selecting relevant communities for analysis involves two preliminary steps. First, the researcher needs to 
determine research questions and to identify forums and platforms that are the most appropriate for these questions. The research focus on the co-creation of consumers belonging to virtual communities and their influence on brands. This netnographic study targets brand communities on social networks such as Facebook and other platforms used by the Axe brand. Accordingly, it is necessary to obtain as much information as possible on forums about individuals, group members or groups which are relevant for this research. Five criteria are proposed in the selection of online communities (Kozinets, 2002): a better choice of segment, individuals or groups of interest providing a better-targeted research; a high traffic of Facebook users posting comments; a large number of posted messages; a richer and more detailed source of data; and more interaction between members. By taking into account these criteria, the Axe brand community has finally been selected (specifically the Facebook community pages "Effet Axe" (the Axe Effect) in France and "Axe Dark Temptation" in Tunisia). The choice to study the Axe brand community happens to be especially interesting thanks to the set-up of participative events attracting many young people, which leads to an increase in the traffic of internet and Facebook. Moreover, during a qualitative exploratory analysis performed in the two-country study, the example of the Axe brand was highlighted, Axe being perceived as a youthful and empowering brand attracting young seducers and seductresses. Indeed, young people clearly identify themselves with this brand. All this renders possible the gathering of rich and detailed information and the possibility for an analysis concerning two participative events in two different countries.

\section{$2^{\text {nd }}$ step: Data collection and analysis}

In this phase, the analysis was based on data coming from various website messages (Kozinets, 2002) to provide reliable and relevant interpretation.

\section{$3^{\text {rd }}$ step: Members checking/verification by members}

The research results have to be shared with the community members who were the focus of the study so that they can provide their feedbacks. This phase has allowed checking the results of netnographic which are presented below.

\section{Results of the Ethnographic Study of the Axe Brand Community}

\subsection{Description of the Participative Events}

Two events was selected that best represented the brand. In order to fully grasp the brand community's participative phenomenon to the various co-creation contests launched by Axe, the article chose to analyze the Axe's participative events in France and Tunisia which took place at the same time. The objective was twofold: first, to understand how and why online communities participated to the brand's contests. Second and most importantly, I seek to understand how co-creation could influence the perception of a brand within communities located in two distinct geographic areas given that — as explained previously (Sitz \& Amine 2004).

\subsection{1 "Axe Dark Temptation": A Seduction Competition}

The starting idea was to establish an Axe studio in the Tunisian universities' halls in order to take pictures (from the $1^{\text {st }}$ of August 2012 till the $30^{\text {th }}$ ). The principle was the following: every boy had to seduce as many girls as possible and convince them to take an 'Axe' picture, thereby displaying a sense of creativity and imagination. Every picture would be posted on Facebook and would be subjected to a vote. The best picture's winner would be awarded a price of Dt 5,000 (€2,500). The picture is presented below:

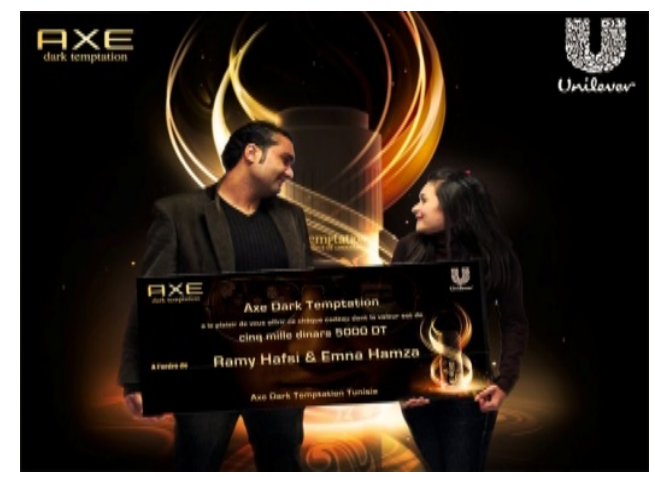




\subsubsection{The "Axe Boat": 10th Edition}

The second Axe Boat event, displayed on the "Axe Effect" Facebook page, is much anticipated by all the Axe brand community. Every year, Axe organizes the "Axe Boat" event. This boat represents the brand and is launching events in every city it arrives at. In 2012, the "Axe Boat" celebrated its 10th years of existence. About 30,000 people got on board the boat, 132 parties took place and more than 50 cities from the Atlantic and Mediterranean coasts have been crossed since its creation in 2003. From the $30^{\text {th }} \mathrm{July}$ till the $7^{\text {th }}$ August 2012, during its $10^{\text {th }}$ summer tour edition, the Axe boat invited clubbers, club members as well as the brand community to get on board this prestigious yacht and have fun. Once on board, the guests discovered a glamorous, VIP and fun atmosphere.

The $10^{\text {th }}$ edition programme particularly targets brand community members: the objective is to make Axe fans real jet setters with 6 stopovers expected in the Mediterranean basin including one exceptional launching date in one of Azur Coast's most glamorous cities. This $10^{\text {th }}$ edition was also an opportunity to offer Axe fans numerous surprises and exclusive products both during the tour and also on the "Axe Effect" fan page (facebook.com/axefan). For its 10 years anniversary, the Axe Boat tour ended with a "Full Moon Party" which gathered French and International celebrities around an exceptional concert.

The requirement to participate and win Axe Boat tickets and go on tour with the Axe team is to subscribe to the "Anarchy Run" facebook application game and beat the scores of other members. This is called an "advergame", ie., one online game with the brand signature. The rule is to grab the last VIP pass which allows its owner to access to a party on the Axe Boat. The game's trick is that an alarm is triggered; consequently the player needs to thwart the premises and disarm the guards tracking him. In order to win, the player has to use, as weapons, the brand's latest deodorants "For Him" and "For Her" enabling them to escape. Every day, the player having the best score wins a VIP pass. At the end of the game, the player having the highest score wins the ultra VIP pass.

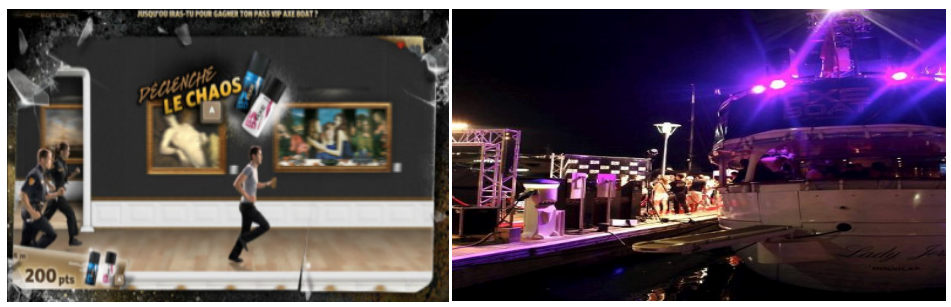

\subsection{Interpretation and Data Analysis}

The brand has all the necessary attributes to mobilize the support of community members.

\subsubsection{The Setting in a Universe of Seduction through the Brand's Identity Prism}

The brand's community identity prism (Kapferer, 1991) distinguishes, on one hand, the brand's external characteristics - that is its physique, relationship, reflection; and, on the other hand, its internal characteristics: its personality, culture and self-image (c.f. Annex 3). The brand's identity prism aims to compare the ideal identity wanted by the brand with the image perceived by the community. The Axe brand's identity prism was elaborated from TV advertisements, the observation of pictures and videos shared by the members and from the analysis of comments on the various pages visited on the social networks.

Personality: Community members identify themselves with the Axe brand personality:

1) The openness, meaning the sensitivity to the esthetical aspect.

2) The extraversion, meaning the social characteristic and seeking people's company (which is perceived through the collective participation of members in different events of the brand, through the pictures of young people during the "Axe Dark Temptation" campaign, "the Axe boat" tour and the "Anarchy Run" game to have fun).

3) The agreeableness, meaning the "bon-vivant" characteristic (members like to party), good mood and seduction. These three features are the intrinsic characteristics of a brand qualified as "sexy", "fun" and "cool" and they, consequently, become the characteristics of members.

Culture: The Axe brand fits into a culture of seduction in a world of fragrances. The brand develops fragrances with different flavors that reveal and strengthen men's seductive power. The Axe brand community members 
strongly identify themselves with this culture and share the same values and norms.

Self-image: The community members glorify the brand and identify themselves with its characteristics, in this case beauty and seduction, as the brand's slogan states: "Spray more, get more". Thanks to the simple use of Axe, men become more handsome, attractive and seductive.

Physique: Physique consists in a whole range of deodorant products with different flavors, a packaging with a round shape and an advertising slogan: "Spray more, get more". The logo is either black or white.

Relationship: The brand helps men to be more attractive to women and brings them the necessary self-confidence to be able to flirt with girls. The brand community members communicate directly with the brand. Consequently, the relationship between the brand and its consumers can be described as close and friendly.

Reflection: the brand represents young and dynamic seducers and seductresses (they party and dance).

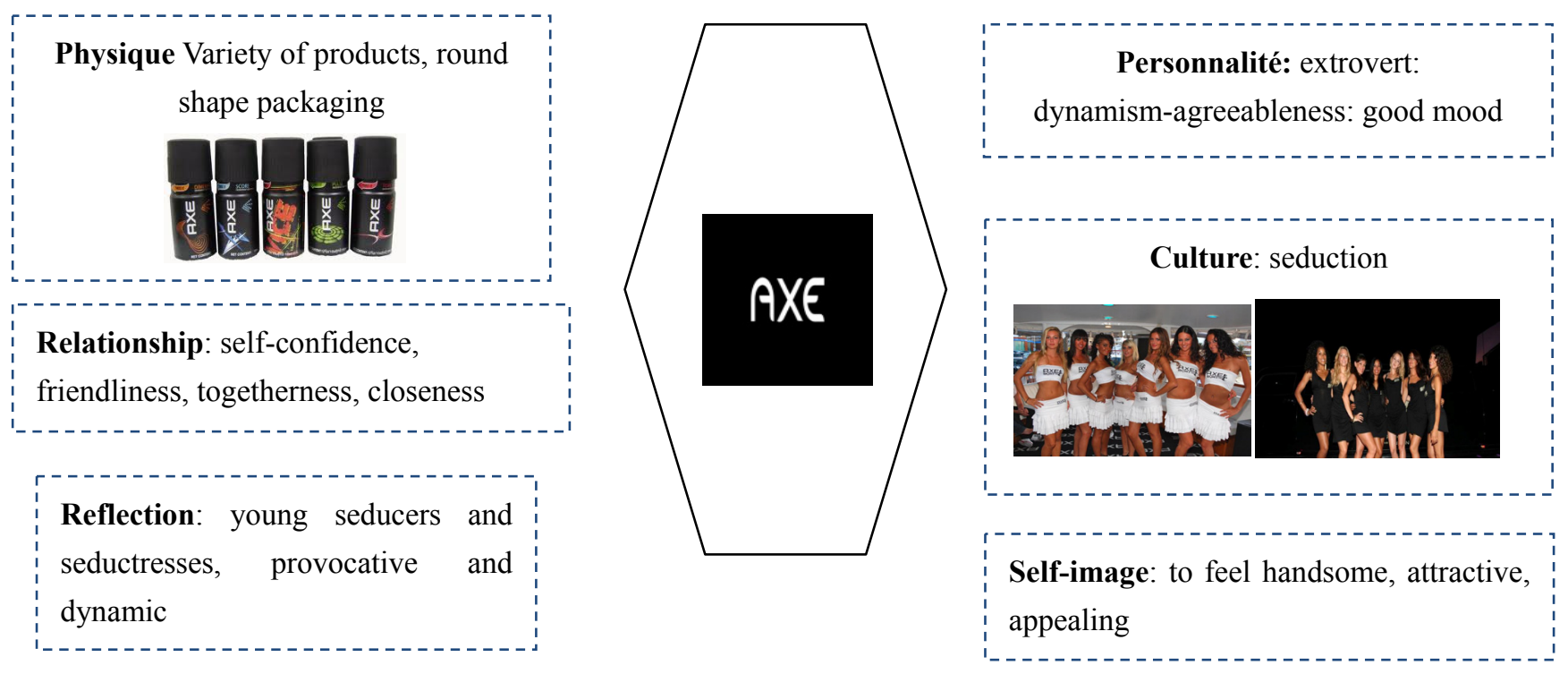

Figure 1. Brand's identity prism of Axe

This analysis concludes that there is no gap between the positioning wanted by the brand and the positioning perceived by the community. Thus, there is very strong brand identification; the brand's identity becomes the community's identity. Brand community members become the brand's ambassadors, promoting an "Axe way of life". The brand's values, norms and culture become theirs and members will take its defense despite any opposition. The events, games, contests organized by Axe create solidarity between members. The latter actively participate and recruit other members. In this way, the community is able to influence members' perceptions and actions (Algesheimer, Dholakia, \& Herrmann, 2005) and their capacity to co-create.

\subsubsection{Interpretation of Events and Co-creation}

The first "Axe Dark Temptation" event is a relevant example of co-creation as defined by Prahalad and Ramaswamy: "co-creation is a new technique of management, in which consumers and producers join in to create products and experiences". The "Axe Dark Temptation: Tunisia" contest launched by the brand brings in passive members for the communication strategy (they only participate through voting) and active members (who directly participate in the event through posting pictures of themselves for instance). Active members create content: they have to showcase creativity when posting a picture. Thus, there is both the creation of an advertising concept and the creation of experiences shared by participants.

The second "Axe boat" event is not an example of co-creation offer per se. Indeed, the Axe brand calls on its Facebook community members not to create an offer or a product, but to participate in a game and in the Axe boat tour. Nevertheless, co-creation is still occurring. First, there is a co-creation of experiences at level of the "Advergame" involving an active participation and identification with the brand's members; secondly, the 
participation to the Axe boat tour offers a unique experience to participants: the community members create their own experiences. Moreover, the immersion in the online brand community as well as the examination of the "Axe boat" shows that community members interact even more when it comes to a specific event. Comments are not only about the event, other creative ideas can be found on the Facebook page. The interaction between members continues outside the event organized by the brand. The brand encourages the community members to interact, create, comment, and to share their opinions. The "Advergame" is therefore an ideal advertising tool for co-creation.

\subsubsection{Classification of Co-creation: Illustration by Axe Brand}

Inspired by Cova.'s model (2008), this classification integrates two criteria for co-creation: interaction (strong and weak) and duration (on a short-term basis that is punctual and limited to the event; and on a long-term basis that still takes effect after the event):

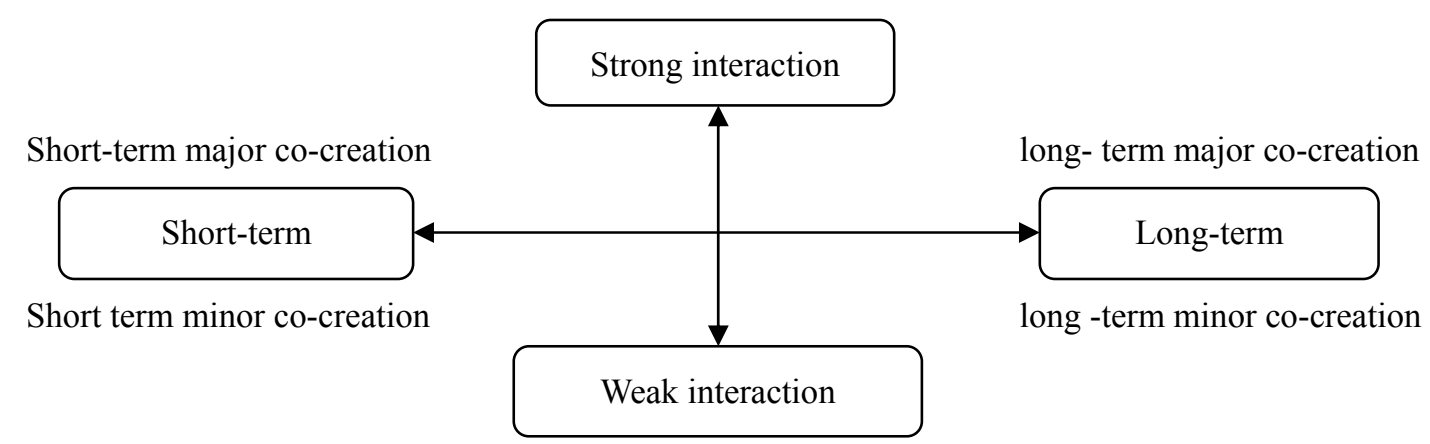

Figure 2. Classification of co-creation Axe events

Here, four types of co-creation are identified: major co-creation with a strong interaction component on a long-term basis, major co-creation with a strong interaction on a short-term basis, minor co-creation with a weak interaction on long-term basis and minor co-creation with a weak interaction on short-term basis.

The level of interaction defines the type of co-creation. In case of a strong interaction, co-creation will be defined as "major". On the other hand, in case of a weak interaction, co-creation will be qualified as "minor". The examination of the two communities in the French and Tunisian Facebook pages confirmed the usefulness of such a distinction (cf. Annex 2).

Major long-term co-creation refers to the strong interaction existing between the members of a same community and between the community and the brand itself. This interaction is maintained over time and continues outside the participative event. The "Axe Boat" event displayed on the "Axe Effect" Facebook page demonstrates that, beyond the co-creation of shared experiences, co-creation occurs outside the Axe boat event itself. To be sure, interaction starts and continues before and after the event. The brand community is not only interested in sharing the Axe Boat tour's pictures or to post comments regarding an event. Members give also their feedbacks either on a product or the brand and provide new idea to the brand. The community's influence over brands is even more important than members' interaction. "The creative contribution can happen when the participant is best suited to work on it, with maximum flexibility, and not only during creative sessions at a predetermined time" (Divard, 2010).

Members share the same values, namely seduction and flirt, and are very active: they participate in the "Anarchy Run" game and in the "Axe boat" events, and they don't miss any occasion to express themselves, give their opinions and participate in every event organized by Axe. The incentives for participating are mostly intrinsic: entertainment and idealism (Divard, 2010). They participate in an event in order to enjoy themselves. People who commit themselves to participate to marketing operation do so because it is in accordance with their values (Idealist).

Short-term minor co-creation refers to the example of the "Axe Dark Temptation" campaign in Tunisia where one can see consumer participation generally belonging to online communities (for instance facebook or twitter, forum websites and so on), but who share little or no common values with the brand. Participation occurs on a short-term or temporary basis, generally corresponding to the duration of the participative event. Interaction between community members is limited during the event (for instance they comment pictures and videos). 
Member feedbacks and reactions stop at the end of the competition. Internet users lose interest for the Facebook page; they don't react anymore and are expecting a new event to be launched. From this observation one can conclude that the participation in the "Axe Dark Temptation" contest is mainly motivated by the financial profit and by the experience of conviviality and sharing nice moments (Cova, 2011). "And indeed, I participated in this competition mostly to have fun, I saw my friends participate and I wanted to do the same!! I also thought that the idea and atmosphere were very nice and, after all, why not earning money by doing something fun?"

Short-term major co-creation: Danone has designed an advertising campaign to celebrate the launching of its new product. Internet users have participated in the elaboration of new advertising concepts and in the production of videos designed for the competition. The competition is temporary, on a short-term basis and limited to the participative event. Interaction is strong since winners have been invited by the brand and advertising agencies to discuss about the advertising concept created by the competition winner: As asked Yannig from EYeka "I am invited by Danone to attend, with two or three persons from e-Yeka, a workshop in the Danone's offices in Turkey and they discussed about their concept, there was an advertising agency etc. And, as a result, the consumers - the "creative ones", the "winners"-chatted and then they talked with the brand and the agency. But, anyway, for me, it is one of the best examples of co-creation, in the sense that there was an interaction ..."

Long-term minor co-creation: In this case, interaction is weak between the community members and between the brand and the community; and it takes place on a long-term basis with, for instance, Starbucks' ideas box "My Starbucks Idea" or Carrefour's. In these two examples, consumer inputs only consisted in a simple improvement of the existing offer. Members submit their ideas on the company's platform and to the other members without interacting with the brand. The ideas box remains permanently open; it is reusable on the long run.

\subsection{The Negative and Positive Effects of the Co-Creation of Axe's Online Brand Community}

The Axe community's netnography study on the "Axe Effect" Facebook page has made it possible to draw negative and positive effect of co-creation.

\subsubsection{The Positive Influence of the Axe Community over the Brand}

\section{Brand stretching: the co-innovation}

Community members can indirectly express latent needs and bring new ideas. The brand can take advantage of their comments and inputs to launch new offers and products onto the market and to improve old products (co-innovation) (Cova, 2008). The innovative propositions are made beforehand the production process. For example, Julien one member asked: "Oh I just clicked! Why Axe would not roll out a shaving cream?" Axe's reply: "Thanks for the idea Julien, we'll keep it under our hat!"

\section{Improvement of the brand image}

The brand image refers to "perceptions about a brand as reflected by the brand associations held in the consumer's memory" (Keller, 1993). The brand image creates value by helping consumers to process information, differentiating the brand from other ones, creating reasons for buying it, provoking favorable feelings, and favourising brand-stretching (Aaker, 1991). The brand image is "everything that a consumer can associate to a brand" (Korshia, 2000).

Calling on brand communities to make the brand more attractive: this is where lies in the appeal of co-creation. In order for co-creation to succeed, it is necessary to find means to make internet users more involved. The "Axe boat" and "Axe Dark temptation" campaigns succeeded in attracting young people and they have achieved their mission: the brand image is now strengthened thanks to internet users. The Axe brand seeks to achieve young adults' dreams and to fulfill its promise: "spray more, get more". Youc one member sayed: "Today I used the Axe brand and I was hit by on by eight girls".

\section{An intensive communication: a co-promotion in favor of the brand}

A networking effect: the community uses its own network to broadcast the brand advertisements through word-of-mouth. The brand does not only convey a message unilaterally, it takes advantage of the network to communicate multilaterally (c.f. table 3 ). The members create events and are responsible for spreading updates and information about the brand. Indeed, through communities, social networks provide new ways of reaching out and engaging with their members and/or with a brand. The community can act as a co-promotion tool (Cova, 2008). Etienne a members asked: "Hello, I am studying at the Ecole des Ponts et Chaussées, an French engineering School. At the beginning of the academic year, in September, a new student's orientation weekend 
(WEI in French) will be organized. To do so, us, the second-year students, are going to created groups composed of 5 to 6 students who will welcome the future first-year students. With some friends, we wanted to create a group called "the Muchas MarWEIcas, referring to one of your advertising campaigns that we found particularly funny. Consequently, I would like to know if you had any promotional tools that would help us organize a nice weekend party and we would promote your brand at the same time. Thank you in advance".

A willingness to participate to advertisements: the ideas and the conception of advertisements are initiated by consumers. They create events and design advertisements. The Axe community is actively involved in the brand's co-promotion strategy because of their strong identification with Axe. David, defining himself as "an Axe boy", states: "if you are looking for a scenarist for your TV advertisements, contact me by pm. PS: I already have written scenario".

\section{Strong relationship with the brand}

$\rightarrow$ Loyalty, attachment or engagement: the Axe community members don't miss an opportunity to constitute their own collection of the whole range of Axe's deodorants and to showcase it. This shows an attachment or an engagement (Raies \& Gavrard, 2011), even a passion toward the brand that can be translated by a lasting loyalty

$\rightarrow$ Sharing of memories: co-creation reinforces ties between community members. Through games and competitions, they build up intimate relationships because they share the same passion for the brand and common memories. Frederic, an Axe community member, states: "And to think that this idea was born in a small office based in Nation - in Paris-while eating two pizzas and drinking coke. Ten years already. A hug to all that participated in this adventure". Jerome precise: "the Axe Boat was an amazing experience; I was there 4 years ago, such a good time".

The positive effects of the brand community through co-creation are thus numerous. These effects go all the way from the simple communication through word-of-mouth to the improvement of the brand image and the development of both inter-members relationships and between brand community members and the brand. They also demonstrate the importance of this new technique and the direct impact that it can have on brands and enterprises. Other effects have been observed during the qualitative exploratory study: the financial benefits (participants' compensation) permit to get a competitive advantage via co-innovation or a free advertisement made by the brand community. However, co-creation can also have negative effects.

\subsubsection{The Negative Influence of Communities: A Communication in Disfavor of the Brand}

Brand communities are increasingly becoming more powerful. This trend manifests itself through a networking communication and a word-of-mouth strategy that sometimes turns out to be negative. The messages posted by members on social networks can inflict injury to the brand by denouncing false advertising (Zeroo states: "why is it that no woman is hitting on me, it should be working since I'm using Axe, you liars ... false advertising. They are stealing my money...") or by expressing discontent toward a product. Sevap asked: "this is supposed to be antiperspirant and anti-odour! this doesn't have any effect on me !!! .. After an hour, I smell bad and I sweat").

\section{Hindrance to events participation and solidarity with disqualified friends}

Some people decide to unsubscribe from the "Axe Effect" Facebook page to show solidarity towards their friends. This constitutes a drawback for such a brand which counts a lot on the creativity of its community in order to grow. The co-creation of experiences as seen in the "Axe Boat" example is limited to the members who succeed in beating the best scores of the "Anarchy Run" game. Consequently, other members find themselves marginalized, being left over and can't participate in the event, in spite of the attachment they feel toward the brand. This preliminary selection may result in dissatisfaction and can affect the brand image. Jennifer precise: "hello, honestly it is not cool to have disqualified Frederic Vermotte who did his best to ask for all his friends" votes, so just so you know, I'll unsubscribe from Axe".

\section{Conclusion, Discussion and Managerial Implications}

The genesis of co-creation was based on the Service Dominant Logic (Vargo \& Lush, 2004). I ran through (with a chronological evolution) in order to answer several questions: how the co-creation concept has emerged, how the status of the client has shifted from being a customer to a producer and actor and how the "client experience" contributes to value-creation. A brand having a strong identity such as Axe becomes involved in the creation process through the participation of its community in the brand's events. This participation leads to interaction between members and between the brand and members (communication one to many). It constitutes a crucial element for brand value. This interaction generates better ideas and products. Members have a direct impact on the brand: innovation and/or innovations failures, communication in favor and/or in disfavor of the brand, the 
improvement and/or deterioration of the brand image, the resistance of community to change, the repositioning of the brand.

This netnographic research has demonstrated that online consumers appear more active, participative, resistant, activist, playful, social and communitarian than they have ever been before (Cova \& Carrere, 2002). From this study, a new typology of co-creation has been proposed, that is: the minor and major co-creation. This typology is based on two criteria: the duration (short or long-term basis) and the interaction level (weak or strong interaction). Co-creation implies interaction over a shorter or longer period. Indeed, brand's co-creation won't have any effect if the brand community members don't interact or participate in events and competitions and don't share their opinions and comments etc. It would be interesting to look into the reasons why they refuse to participate and what could encourage them to interact. To do so, projective techniques can be used.

The results of netnographic analysis have shown that brand communities, through co-creation, influence brands, most of the time positively but sometimes negatively when the brand doesn't respect the commitments made.

Nowadays, communities increasingly require their favorite brands to be more actively involved in their activities. The advertising messages co-created with brands are a good indication of what consumers are dreaming about (seduction, money, happiness). Hence, it is necessary for enterprises to resort more systematically to co-promotion. However, one should be careful with this technique: opponents to brands are likely take advantage of this opportunity to create messages denouncing what they consider as the brands' bad deeds. As a matter of fact, on the US market, a four-by-four car brand having proposed internet users to create their own TV advertising spots saw popped up on social networks several spots denouncing the polluting nature of its cars (Reniou, 2009), which resulted in negative effects on the US brand.

I demonstrate how brand communities can influence brands through co-creation. I explain how the brand identity prism will reinforce a strong brand community that can contribute to co-creation and I draw up a classification of co-creation operations. These results need to be extended to other examples.

\section{Limits and Future Researches}

The main limit of the empirical study is the generalization of results. Internet studies all present limitations. Indeed, the interpretation of information has to be reliable. And yet, once on internet, researchers can be confronted to a deformation of online information. As regards to this research, this effect is smaller because the exploratory study of consumers and interviews of experts led to similar results as those of the netnograhic research.

The netnographic study focused on only one illustrative example of the Axe brand community. However, in order for the result to be generally applicable, there is need for there to be other brands.

It is necessary to consider within the same brand and within others several co-creation examples in order to validate the classification of co-creation which has been identified.

In addition, it would be essential to generalize the use of the Brand Identity Prism (Kapferer, 1991) to create a strong identity brand. This would be an indispensable precondition to the constitution of a community attached to the brand and that would adhere to its values, norms, culture and that would constitute a real incubator of co-creation. It would actively participate in the innovative process by becoming the strong link of this process. And the brand community concept then transcends borders (Sitz \& Amine, 2004).

Through the study of other examples, we have noticed two key success factors of co-creation:

$\rightarrow$ It is efficient inasmuch as it concerns a small number of consumers: the ones who want to participate in participative events 5\% consumers (Reniou, 2009) or the ones who have a real expertise and who can participate in these events (for instance the Electrolux Design Lab is attended for designers or students in this field).

$\rightarrow$ The whole company has to be involved in a lasting manner by establishing a constant dialogue between clients and companies employees (for instance Oxylane had to relocate its R\&D team to certain consumption areas in order develop the Decathlon brand (seaside and mountains areas)

Finally, managers have to find ways to reduce the risk of consumers taking control over brands. They have to know in which case resorting to co-creation is best appropriate and they have to balance consumers' power and counter power and to initiate a co-power approach. Further investigation of the effects of co-creation through brand communities should be looked into, especially the following questions: what is the level of control over brand? How to fix clear limits for brand community members? 


\section{References}

Abidi-Barthe, A., \& Kaabachi, S. (2010). La co-création d'expériences de consommation par le Web 2.0. Journal of Internet Banking and Commerce, 15(2), 4-5.

Algesheimer, R., Dholakia, U. M., \& Herrmann, A. (2005). The social influence of brand community: Evidence from Euroên car clubs. Journal of Marketing, 96(3), 19-34. http://dx.doi.org/10.1509/jmkg.69.3.19.66363

Bonnemaizon, A., \& Batat, W. (2011). Les représentations managériales des compétences du consommateur : la co-création de valeur est-elle toujours possible? Le cas des consommateurs d'énergie, Actes du $27^{\text {ème }}$ congrès de l'AFM, Association Française de Marketing, Bruxelles, 1-22.

Bonnemaizon, A., Moreau, F., Cadenat, S., \& Renaudin, V. (2011). Au boulot, cher client! Une approche interprétative de la participation ordinaire du consommateur. $27^{\text {ème }}$ congrès de l'AFM, Bruxelles. Belgique, 24-37.

Bendapudi, N., \& Leone, R. P. (2003). Psychological implications of customer participation in co-production. Journal of Marketing, 67(1), 14-28. http://dx.doi.org/10.1509/jmkg.67.1.14.18592

Boyle, E. (2007). A process model of brand cocreation brand management and research implications. Journal of Product \& Brand Management, 16(2), 122-131. http://dx.doi.org/10.1108/10610420710739991

Christodoulides, G., Jevons, C., \& Bonhomme, J. (2012). Memo to Marketers: Qantitative Evidence for Change How User-Generated Content Really Affects Brands. Journal of advertising research, 52(1), 53-64. http://dx.doi.org/10.2501/JAR-52-1-053-064

Cova, B. (2006). Développer une communauté de marque autour d'un produit de base: l'exemple de Nutella The community. Décisions Marketing, 42(2), 53-62.

Cova, B. (2008). Consumer Made: Quand le consommateur devient producteur. Décisions Marketing, 50(2), $19-27$.

Cova, B. (2011). Communautés, Tribus et réseaux sociaux. In J. M Lehu (Ed.), MBA marketing, coord (pp. 455-480). Paris: Eyrolles.

Cova, B., \& Dalli, D. (2009). Working Consumers The Next Step in Marketing Theory. Sage Handbook of Marketing Theory (pp. 476-493).

Cova, B., \& Carrere, V. (2002). Les communautés de passionnés de marque: opportunité ou menace sur le net? Revue Française de Marketing, 119-130, 189-190.

Cova, B., \& Ezan, P. (2008). Le consommateur-collaborateur : activités, attentes et impacts. Le cas du passionné de Warhammer, $13^{\text {ème }}$ Journées de Recherche en Marketing de Bourgogne, Université de bourgogne, CERMAB, session 9, Racines socio-culturelles de la consommation, 1-20.

Cova, B., \& White, T. (2010). Counter-Brand and Alter-Brand Communities the Impact of web 2.0 on tribal marketing approaches. Journal of Marketing Management, 26(3-4), 256-270. http://dx.doi.org/10.1080/02672570903566276

Curbatov, O., \& Louyot-Gallicher, M. (2011). Le knowledge marketing et les compétences du consommateur au service de la co-création, Actes du $11^{\text {ème }}$ congrès de l'AFM, Bruxelles, Belgique.

Darpy, D., \& Gomy, P. (1999). Le prisme d'identité de la marque, outil pour l'analyse historique des publicités-30 ans de DIM. Cahier de recherche n 269, centre de recherche DMSP Dauphine Marketing et Stratégie Prospective.

Divard, R. (2010). Le marketing participatif (1st ed.). les topos+: Dunod.

Eiglier, P. (2002). Le service et la servuction, Centre d'études et de recherche sur les organisations et la gestion. Working paper, $n$ 627, IAE d'Aix Marseille, 1-23.

Eiglier, P., \& Langeard, E. (1987). Servuction le marketing des services (1st ed.). Paris: McGraw-Hill Science International.

Ezan, P., \& Cova, B. (2008). La confusion des rôles de consommateur et de producteur dans les communautés de marque : une complicité dangereuse ? Décision Marketing, 52, October-December, 51-60.

Fuller, J. (2010). Virtual Co-Creation of New Products and its Impact on Consumers' Product and Brand Relationships Toombs, L. Academy of Management Annual Meeting, Canada.

Giannelloni, J. L. \& Vernette, E. (2012). Etudes de marché (1st ed.). Vuibert. 
Gouillart, F, J., \& Ramaswamy, V. (2011). L'entreprise co-créative Clients, employés, fournisseurs... Quand l'organisation s'ouvre à ses partenaires (1st ed.). Vuibert.

Jo Hatch, M., \& Schultz, M. (2010). Toward a theory of brand co-creation with implications for brand governance. Journal of Brand Management, 17, 590-604. http://dx.doi.org/10.1057/bm.2010.14

Korchia, M. (2000). Une nouvelle typologie de l'image de marque. Actes du 16ème congrès international de l'Association Française du Marketing, Montréal, Canada. Mai.

Kozinet, R. V. (2002). The Field Behind the Screen: Using. Netnography for Marketing Research in Online Communities. Journal of Marketing Research, 7(1), 61-72. http://dx.doi.org/10.1509/jmkr.39.1.61.18935

Kozinet, R. V. (2006). Click to connect: netnography and tribal advertising. Journal of advertising research, 46, $278-288$.

Kreziak, D., \& Frochot, V. (2011). La co-construction de l'expérience en station ski. Décision Marketing, 64(2), 23-33.

Lapert, D., \& Munos, A. (2009), Marketing des services (2nd ed.). Les topos+: Dunod.

Lusch, R. F., \& Vargo, S. L. (2006). Service-Dominant Logic: Reactions, Reflections and Refinements. Marketing Theory, 6(3), 281-288. http://dx.doi.org/10.1177/1470593106066781

McAlexander, J. H., Schouten, J. W., \& Koeing, H. F. (2002). Building Brand Community. Journal of Marketing, 66, 38-54. http://dx.doi.org/10.1509/jmkg.66.1.38.18451

Merz, M., Yi, H. A., \& Vargo, S. L. (2009). The evolving brand logic: a service-dominant logic perspective. Journal of the Academy of Marketing Science, 37(3), 328-344. http://dx.doi.org/10.1007/s11747-009-0143-3

Meyronin, B., \& Ditandy, C. (2011). Du management au marketing des services (2nd ed.). Améliorer la relation client-Développer une véritable culture de service. Marketing communication, Dunod.

Michon, C. (2009). Le rôle de l'identité: Source dans la création de l'identité de marque. Congrès International Paris Venise des Tendances du Marketing en Europe, Venise.

Mills, P. K., \& Morris, J. H. (1986). Clients as Partial Employer of Service Organizations Role, Academy of Management Review, 11(4), 726-735.

Moreno, C., \& Besson, M. (2009). Créer de la valeur dans les services: l'exemple de l'iPhone sur le marché français. Service Science and Network Theory, 16-19, Capri, Italy: EIASM.

Muniz, J. A. M., \& O’Guinn, T. C. (2001). Brand community. Journal of Consumer Research, 27(4), 412-432. http://dx.doi.org/10.1086/319618

Payne, A. F., Storbacka, K., Frow, P., \& Knox, S. (2009). Co-creating brands: diagnosing and designing the relationship experience. Journal of Business Research, 62(3), 379-389. http://dx.doi.org/10.1016/j.jbusres.2008.05.013

Pearse, J. (2011). Co-creation communities can be goldmines for brands: Danone used its community of 400 women to develop a new product in just few months for conception. Leader, 17 March.

Prahalad, C. K., \& Ramaswamy, V. (2004). Co-creating unique value with customers. Strategy \& Leadership, 32(3), 4-9. http://dx.doi.org/10.1108/10878570410699249

Prahalad, C. K., \& Ramaswamy, V. (2004). Co-creation experiences: the next practice in value Creation, Journal of Interactive Marketing, 18(3), 5-14. http://dx.doi.org/10.1002/dir.20015

Prahalad, C. K., \& Ramaswamy, V. (2000). Co-opting customer competence. Harvard Business Review, 78(1), 79-87.

Prahalad, C. K., \& Ramaswamy, V. (2002). The co-creation connection. Strategy and Business, 20, 50-61.

Prahalad, C. K., \& Ramaswamy, V. (2003). The new frontier of experience innovation, MIT Sloan. Management Review, 44(4), 12-18.

Pongsakornrungsilp, S., \& Schroeder, J. (2011). Understanding value co-creation in a coconsuming group. Marketing Theory, 11(3), 303-324. http://dx.doi.org/10.1177/1470593111408178

Raies, K. \& Gavrard-Perret, M. L. (2011). Intention de fidélité à la marque des participants à une communauté virtuelle de marque: le rôle dual de l'engagement. Recherche et Applications en Marketing, 26(3), 23-43. http://dx.doi.org/10.1177/076737011102600302 
Reniou, F. (2009). Opérations participatives des marques: pourquoi et comment faire participer les consommateurs? De la compréhension des opérations participatives et des motivations des consommateurs à s'y engager à l'analyse de leurs effets sur la marque. Thèse de Doctorat Sciences de Gestion, Université Paris Dauphine.

Schau, H. J., Muñiz, J. A. M., \& Arnould, E. J. (2009). How Brand Community Practices Create Value. Journal of Marketing, 73(5), 30-51. http://dx.doi.org/10.1509/jmkg.73.5.30

Schouten, J. W., \& McAlexander, J. H. (1995). Subcultures of Consumption: An Ethnography of the New Bikers. Journal of Consumer Research, 22, 43-61. http://dx.doi.org/10.1086/209434

Sitz, L., \& Amine, A. (2004). Consommation et groupes de consommateurs, de la tribu postmoderne aux communautés de marque: pour une clarification des concepts, 3èmes Journées Normandes de la consommation, Rouen, 11 et 12 Mars.

Vargo, S. L., \& Lusch, R. F. (2004). Evolving to a new dominant logic for Marketing. Journal of Marketing, 68, 1-18. http://dx.doi.org/10.1509/jmkg.68.1.1.24036

Vargo, S. L., \& Lusch, R. F. (2008). Why 'service'. Journal of the Academy of Marketing Science, 36(1), 25-38. http://dx.doi.org/10.1007/s11747-007-0068-7

Vernette, E., \& Tissier-Desbordes, E. (2012). La participation du client, la co-production, la co-création: un nouvel eldorado pour le marketing? Décisions Marketing, 65(1), 212-215.

Von Hippel, E. (1986). Lead users: a source of novel product concepts. Management Science, 32, 791-805. http://dx.doi.org/10.1287/mnsc.32.7.791

Viseur, R. (2007). Co-créateur:les apports du client créatif dans le design de produits nouveaux. Ateliers de la recherche en design. Bordeaux, 11 Décembre.

Tables

Table 1. Comparison of the two Axe events to co-creation

\begin{tabular}{|c|c|c|}
\hline $\begin{array}{l}\text { Event and Facebook } \\
\text { page }\end{array}$ & $\begin{array}{l}\text { Facebook page : Axe Dark Temptation : } \\
\text { competition of seduction (Tunisia) }\end{array}$ & Facebook page : Axe Boat (France) \\
\hline $\begin{array}{l}\text { Incentives } \\
\text { (why?) }\end{array}$ & Extrinsic incentives (financial ...) & $\begin{array}{l}\text { Intrinsic incentives: } \\
\text { Entertainment: sharing of collective experiences,living } \\
\text { individual experiences } \\
\text { Idealism: the brand and the communities share the } \\
\text { same values }\end{array}$ \\
\hline Participants (who?) & $\begin{array}{l}\text { University students } \\
\text { Passive participants: people voting } \\
\text { Active participants: showcasing an attitude when } \\
\text { taking a picture }\end{array}$ & $\begin{array}{l}\text { The brand community members } \\
\text { Active participants: participating in games and events }\end{array}$ \\
\hline $\begin{array}{l}\text { Duration of the } \\
\text { participation (when?) }\end{array}$ & Temporary, limited to the duration of the event & $\begin{array}{l}\text { Every year: regular } \\
\text { Continuous exchange throughout the year, outside the } \\
\text { participative events }\end{array}$ \\
\hline $\begin{array}{l}\text { Interaction between } \\
\text { participants and brands }\end{array}$ & Weak interaction & Strong interaction on a long-term basis \\
\hline Co-creation effects & $\begin{array}{l}\text { Minor co-creation: } \\
\text { Co-creation of a temporary offer (in this case the } \\
\text { advertising concept) } \\
\text { Interaction is weak between participants and the } \\
\text { brands, it is limited to the duration of the event }\end{array}$ & $\begin{array}{l}\text { Major co-creation: } \\
\text { Co-creation of experiences for people participating in } \\
\text { the event. } \\
\text { Co-creation of new offers outside the participative } \\
\text { events. In this case, there is a strong interaction }\end{array}$ \\
\hline
\end{tabular}


Table 2. Kapferer's Brand identity Prism (1991)

\begin{tabular}{ll}
\hline Physique & the tangible qualities of the brand, what is externally perceived? For instance: product features, packaging \\
Physique & the tangible qualities of the brand, what is externally perceived? For instance: product features, packaging \\
Relationship & the relationship between the brand and the consumer: exchange or transaction (Kapferer, 1998) \\
Reflection & The brand or the product's target \\
Personality & the brand's personality traits, what it conveys through its brand image. The personality consists on 5 factors based on the \\
& OCEAN model: Openness, Consciciouness, Extraversion, Agreableness, Neuroticsm \\
Culture & the brand's values developed over time. \\
Self-image & This is what the consumer is looking for and finds in the brand \\
\hline
\end{tabular}

Table 3. unilaterale Communication (one to one) vs multilaterale communication (one to many)

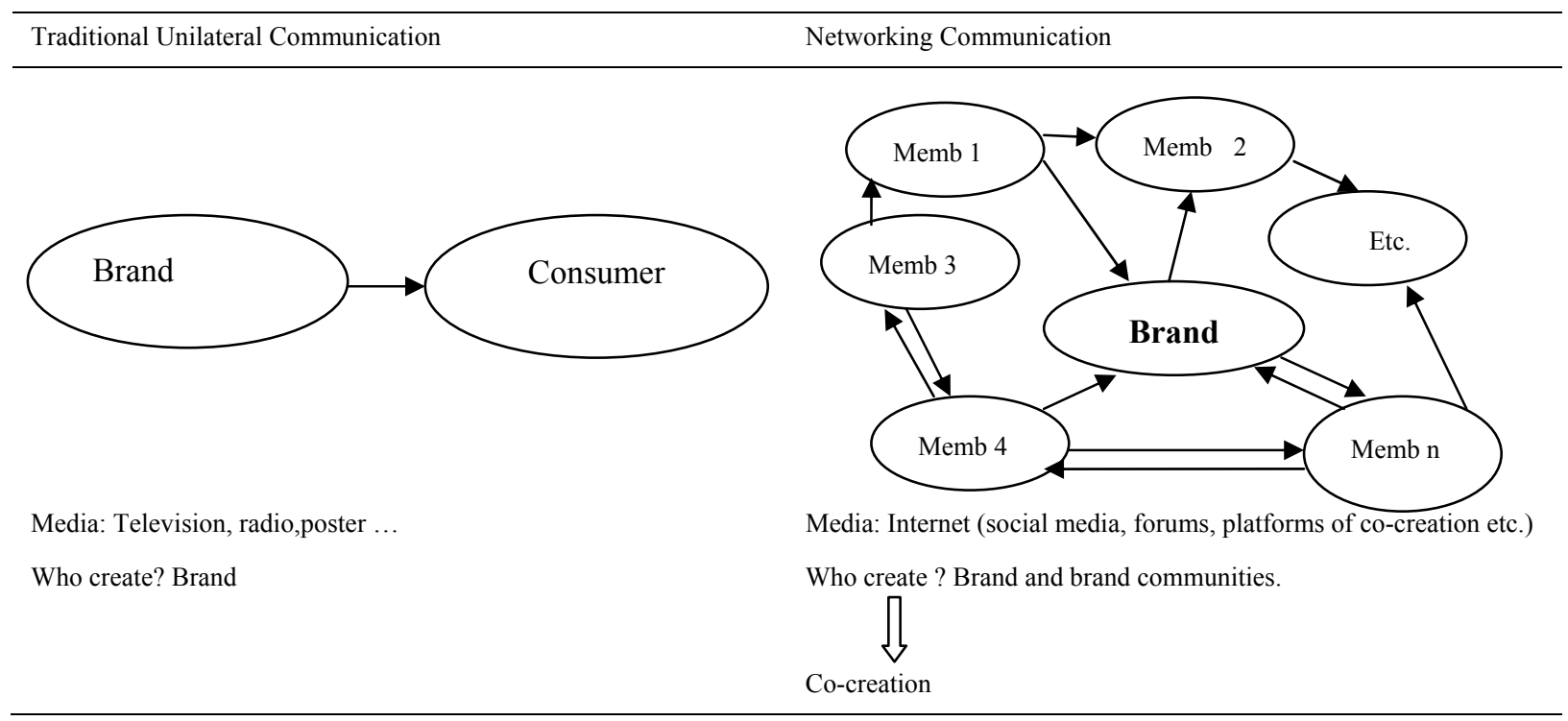

Table 4. Evidences of consumers willingness to belong to the Axe brand culture

\begin{tabular}{ll}
\hline & \multicolumn{1}{c}{ Evidences of consumers willingness to belong to the Axe brand culture } \\
\hline Gerald & $27^{\text {th }}$ of June "I want to design advertisements for Axe \\
Axe Effect & Do you know that recently, we have permitted to 8 of our fans to participate in the design of TV advertisements? \\
Raphael & I want to star in an Axe TV advertisement and also to go on board the Axe Boat =D Love Axe $<3$ \\
Axe Effect & for the Axe boat, we should be able to arrange something over the next few days ... ;) \\
Severine & This video is so cool, I'd like so much to participate in an Axe TV advertisement, that would mean a lot to me \\
\hline
\end{tabular}


Table 5. Evidences of consumers' engagement and loyalty toward the brand

\begin{tabular}{ll}
\hline & Evidences of consumers' engagement and loyalty toward the brand \\
\hline Ambroise: & whole range of Axe products ! \\
Paul & profitable $:-$ \\
Agnes & what do you plan to do for your armpits? \\
Axe Effect & what a collection! \\
Teddy & thank you, we'll try to do even better next year \\
Coleen & yes, it was a nightmare to find it \\
Coleen & where did she find it? \\
Axe effect & I see someone has begun to stockpile \\
\hline
\end{tabular}

\section{Copyrights}

Copyright for this article is retained by the author(s), with first publication rights granted to the journal.

This is an open-access article distributed under the terms and conditions of the Creative Commons Attribution license (http://creativecommons.org/licenses/by/3.0/). 